\title{
The food sovereignty project: Advancing theory and practioes
}

\author{
Review by Salma Loudiyi * \\ Clermont Auvergne Université, AgroParisTech, INRA, \\ Irstea, VetAgro Sup, UMR Territoires, France
}

Review of The Politics of F ood Sovereignty: Concept, Practice and Social M ovements, edited by Annie Shattuck, Christina Schiavoni, and Zoe VanG elder. (2017). Published by Routledge. Available as hardcover; 162 pages. Publisher's website: https:/ / www.routledge.com/ The-Politics-of-FoodSovereignty-Concept-Practice-and-Social-Movements/ $\underline{\text { Shattuck-Schiavoni-VanG elder/p/ book/ } 9780415787291}$

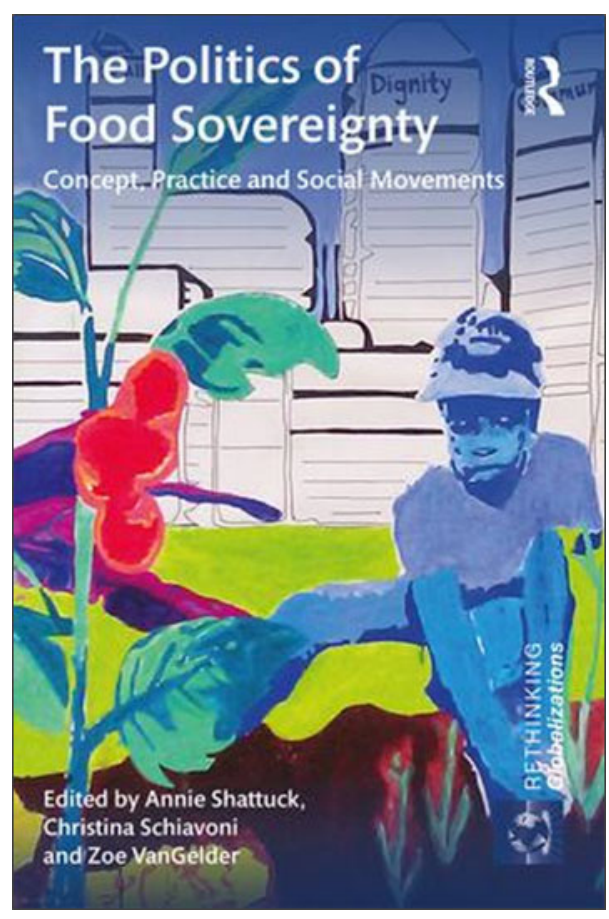

Submitted January 3, 2018 / Published online June 7, 2018

Citation: Loudiyi, S. (2018). The food sovereignty project: Advancing theory and practices [Book review]. Journal of A griculture, F ood Systems, and C ommunity D evelopment, 8(2), 161-163. https:// doi.org/ 10.5304/ jafscd.2018.082.011

Copyright @ 2018 by the Author. Published by the Lyson Center for Civic Agriculture and Food Systems. Open access under CC BY license.

$\mathrm{I}^{\mathrm{n}}$ n T he Politics of F ood Sovereignty: C oncept, Practice and Social M ovements, editors Annie Shattuck, Christina Schiavoni, and Zoe VanG elder bring together some of the seminal contributions of the $Y$ ale McMillan Center Agrarian Studies Program's 2013 conference focused on food sovereignty

* Salma Loudiyi is a geographer and an associate professor at VetAgro Sup, an institute of higher education under the supervision of the French ministry of agriculture and food. She is currently working on place-based food policies in France and the emerging public policies for food sovereignty in Europe. She can be contacted at salma.loudiyi@ vetagro$\underline{\text { sup.fr }}$
("Food Sovereignty: A Critical Dialogue"). These proceedings were originally published in a special issue of the journal $G$ lobalizations (volume 12, issue 4 , 2015). This book is valuable in general as it discusses the upcoming challenges and contradictions of food sovereignty, a rising concept and political movement in the Global South and North. Contrasting with the food sovereignty literature to date, which has mainly focused on the Global South (from which food sovereignty movements have emerged), this book shows how the original idea has expanded to encompass the Global North and urban communities. This book includes cases 
studies from the U.S., Canada, Russia, Peru, and Venezuela, demonstrating that many types of sovereignties may exist and coexist at different scales, which is a big challenge.

The book is structured as follows. In the first chapter, the editors set the stage for the rest of the book by bringing up the real challenges of the food sovereignty movements, namely, the contradictions surrounding scale (local vs. national; communal vs. individual), power relations (sovereignty for whom), gender issues, the disconnect between ideas from the rural south and those from the urban north. Then, the authors highlight the research gaps and issues faced by practitioners when operationalizing food sovereignty.

Chapter 2 and 3 present complementary views on food sovereignty from a human rights perspective. In chapter 2, Philip McMichael, who has published widely on the "agrarian question,"1 presents the multiple issues faced by the food sovereignty movements from the land user's point of view. In chapter 3, Priscilla Claeys presents the work over the last 20 years of La Via Campesina to institutionalize both "rights to food sovereignty" and "peasant's rights" as human rights. She shows how the human-rights perspective has the benefit of bringing together activists from different realities, although the human rights perspective's focus on the individual can have limited effects against capitalism and neoliberalism. La Via Campesina emphasizes an alternative conception of human rights that stresses the collective dimension of the peasants' demands and focuses on the different scales of decision-making.

In chapter 4, Christina Schiavoni draws on Raj Patel's concept of multiple and competing sovereignties to develop a conceptual framework and apply it to an example in Venezuela to examine the competing sovereignties practices through the lenses of scales, geography, and institutions. The different conceptions of scales enable her to emphasize the importance of looking at food sovereignty from a relational perspective as developed in the next chapter. Indeed, some of the most interesting

\footnotetext{
${ }^{1}$ Rooted in Marxist political economy, the agrarian question seeks to answer why family farms have persisted despite increased capitalistic pressures and conflicts over land access.
}

insights of the book are surely those of Alastair Iles and Maywa Montenegro de Wit in chapter 5. They use the concept of relational scale, "the spatial and temporal relationship among processes at different levels, as well as the processes connecting elements between levels" (p. 66), to suggest practical strategies to achieve food sovereignty. What is particularly important with the relational scale approach is that strategies to achieve food sovereignty occur across scales and not solely at the local level. Using the example of the Potato Park in the Peruvian Andes, they show how multiple sovereignties are reached by negotiating and forging partnerships through different scales effectively enabling the Potato Park to gain legitimacy and be recognized as sovereign. This makes food sovereignty a practice of creating connectivity as well as autonomy (p. 74).

Moving from issues of scales in relation to food sovereignty to everyday practices across local contexts, Meleiza Figueroa proposes in chapter 6 to shift from a food-focused analysis to a peoplecentered approach using the example of an urban initiative in the Global North. In other words, she argues that the daily practices of individuals are informed by their resources, histories, knowledges, and personal goals, all of which can be harnessed to advance alternative solutions, gain autonomy, and foster resilience. The people-centered approach then helps us envision political trajectories of food sovereignty considering specific geographical and historical contexts.

Building from chapter 6 , the next four chapters (7 through 10) provide examples of how food sovereignty is necessarily place-based, rooted in unique histories and geographies that produce the very circumstances of contestation and activism: in Russia, food sovereignty is somewhat "quiet" since contestation is weak or seen as such (chapter 7); in Hawaii, anti-GMO struggles are also a place-based food sovereignty movement (chapter 8); in California, "occupy the farm" is a way to promote new norms for land access and food sovereignty in the Global North (chapter 9); and in Manitoba, a community-based food program is seen as way to reinforce food sovereignty in an indigenous context (chapter 10). What is valuable about these four chapters is that they provide examples of 
greater theorization and conceptualization of food sovereignty.

The main contributions of this book are the conceptual developments, such as multiscale food sovereignties, relational scales, and everyday life practices, as well as the examples that move beyond the global focus of food sovereignty (which nevertheless remains important) to subnational and/ or regional levels and from the peasant and rural focus to consider urban experiments. Together, the conceptual development and examples enhance our understanding of the powerful potential of food sovereignty as a project and as a movement. For those who posit that food sovereignty is mostly an ideology or a utopia, this book provides concrete scientific evidence toward sustainable and just ways to transition. A major drawback of the book is that despite the complementarity of the chapters, the editors of the book did not provide a conclusion. Such a conclusion would not only provide an answer to the key interrogations of the book, but would also highlight a research agenda calling for a broadening of food sovereignty research beyond the current focus on the Americas. Indeed, from a European viewpoint, an open call for more comparative research across geographies is urgent to provide more consistency in the exploration of food sovereignty to lead to a greater understanding and stronger theories and conceptualizations across contexts. Thinking about the audience for this edited book, it seems most suitable for graduate students and researchers who already have a grounding in the concept of food sovereignty. 